\title{
Passive Transfer of Hepatitis B Antibodies through Intravenous Immunoglobulin in a Neonate
}

\author{
Transferência Passiva de Anticorpos Hepatite B através \\ de Imunoglobulina Endovenosa num Recém-nascido
}

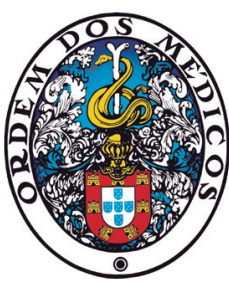

João RATO $\rrbracket^{1}$, Daniela ALVES ${ }^{1}$, Luís RODRIGUES ${ }^{2}$

Acta Med Port 2019 Dec;32(12):782-784 - https://doi.org/10.20344/amp.9792

\section{ABSTRACT}

Passive transfer of antibodies secondary to intravenous immunoglobulin infusion is a rare but important side effect that can lead to the wrong diagnosis and therapeutic decisions. It has never been reported in a newborn. A male newborn, vaccinated against hepatitis $B$ and diagnosed with dilated cardiomyopathy, presented positive hepatitis B core antibodies at 12 days of life. Exclusion of hepatitis B infection was mandatory as it would be a contraindication to heart transplant. Passive transfer of antibodies was confirmed at 44 days of age, after seroreversion of hepatitis B core antibodies. Passive transfer of antibodies after intravenous immunoglobulin infusion can lead to a misleading diagnosis if not recognized. In our patient it could have been especially harmful had it prevented heart transplant. Screening for hepatitis B should be performed at least 1 month after intravenous immunoglobulin infusion.

Keywords: Cardiomyopathy, Dilated; Hepatitis B Antibodies; Immunoglobulins, Intravenous/adverse effects; Infant, Newborn

\section{RESUMO}

A transferência passiva de anticorpos secundária à infusão de imunoglobulina endovenosa é um efeito secundário raro, mas importante, que pode levar a um diagnóstico e decisões terapêuticas erradas. Nunca foi descrito num recém-nascido. Um recém-nascido do sexo masculino, vacinado contra a hepatite B e diagnosticado com miocardiopatia dilatada, apresentou anticorpos anti-core do vírus da hepatite $B$ aos 12 dias de vida. A exclusão da infecção por hepatite B foi obrigatória, pois seria uma contra-indicação ao transplante cardíaco. A transferência de anticorpos através de imunoglobulina endovenosa foi confirmada aos 44 dias de idade, após sero-reversão dos níveis de anticorpos anti-core do vírus da hepatite B. A transferência passiva de anticorpos após a infusão de imunoglobulina endovenosa pode levar a um diagnóstico errado se não for reconhecida. Neste doente poderia ter sido especialmente prejudicial caso tivesse impedido o transplante de coração. O rastreio para hepatite B deve ser realizado pelo menos um mês após a infusão.

Palavras-chave: Anticorpos Anti-Hepatite B; Cardiomiopatia Dilatada; Imunoglobulinas Intravenosas/efeitos adversos; Recém-Nascido

\section{INTRODUCTION}

As intravenous immunoglobulin (IVIG) increases its clinical application it becomes increasingly important for attending physicians to be alert to the risk of passive transfer of antibodies, especially in patients whose seropositivity may lead to unnecessary therapies or even prevent essential treatments. Even though this phenomenon has already been described in literature, ${ }^{1-4}$ it remains little known. We report a case of a neonate with dilated cardiomyopathy who presented positive hepatitis B core antibodies after administration of IVIG.

\section{CASE REPORT}

Male infant, six months old at the time of this report, with no relevant family history. Pregnancy was uneventful, except for an obstetric ultrasonography with left ventricular hyperechogenic focus at the $31^{\text {st }}$ week, which disappeared at the $36^{\text {th }}$ week. No fetal echocardiogram was performed. Maternal serologic screening for human immunodeficiency virus (HIV), hepatitis $\mathrm{C}$ virus (HCV), hepatitis $B$ virus (HBV) and toxoplasmosis was negative, and she was immune to rubella and cytomegalovirus. Delivery occurred at term and had no complications. He received anti-hepatitis $B$ vaccine according to the national vaccination schedule. In the first hour of life the newborn developed respiratory distress with hypoxemia and was transferred to the Neonatal Intensive Care Unit where he received supplemental oxygen therapy. Blood work showed negative infection parameters and the blood culture was negative. Early metabolic screening was normal. A echocardiography screening suggested congenital heart disease. Subsequent evaluation by Pediatric Cardiology on the second day of life was inconclusive. The newborn was clinically stable until the fifth day of life when he presented severe symptoms of congestive heart failure and required invasive ventilation. At eight days of life, the echocardiogram showed dilated cardiomyopathy. He was started on diuretics (furosemide), aldosterone receptor antagonist (spironolactone), digitalis (digoxin), beta-blocker (carvedilol) and calcium channel sensitizer (levosimendan) infusion. Since one of the most common causes for dilated cardiomyopathy are viral infections, he received an IVIG infusion (Octagam ${ }^{\circledR} 5 \%$ ), $2 \mathrm{~g} / \mathrm{kg}$ for 24 hours, at 11 days of life. Etiological studies showed normal carnitine and acylcarnitine levels [total carnitine $72.9 \mu \mathrm{M}$ [reference range (RV) 39.9 - 55.3], free carnitine 48.6 $\mu \mathrm{M}(\mathrm{RV} 29-42)$ and acylcarnitine $24.3 \mu \mathrm{M}$ (RV 8.9 - 15.1)], carbohydrate-deficient transferrin $<20.9 \mathrm{mg} / \mathrm{L}$ ( $R V 28,1-76$ ), normal urinary organic acid chromatography and normal quantitative determination of plasma amino acids with mild hypoaminoacidemia, excluding metabolic disease. Thyroid function was

\footnotetext{
1. Serviço de Cardiologia Pediátrica. Hospital de Santa Cruz. Centro Hospitalar Lisboa Ocidental. Carnaxide. Portugal.

2. Serviço de Patologia Clínica. Hospital de São Francisco Xavier. Centro Hospitalar Lisboa Ocidental. Lisboa. Portugal.

$\square$ Autor correspondente: João Rato. joaorato4@gmail.com

Recebido: 14 de outubro de 2017 - Aceite: 03 de junho de 2019 | Copyright @ Ordem dos Médicos 2019
} 
normal at the $10^{\text {th }}$ and $34^{\text {th }}$ days of life. He had no nutritional deficiencies. An extensive panel of viral serologies was requested for exclusion of a viral cause (coxsackie, adenovirus, echovirus, influenza A and B virus, parvovirus B-19, herpes virus 6, Epstein-Barr virus, cytomegalovirus, HIV 1 and 2, HCV), which was all-negative. Serology for HBV was repeated at the $12^{\text {th }}$ day of life, one day after administration of IVIG, due to insufficient volume of the previous blood sample taken at the eighth day of life. He had positive anti-HBs and anti-HBc antibodies. Complete serology was performed the day after for confirmation: there were again positive anti-HBs and anti-HBc antibodies, negative $\mathrm{HBs}$ antigen, absence of IgM class anti-HBc antibodies, $\mathrm{HBe}$ antigen and anti-HBe antibodies. At 44 days of age, anti$\mathrm{HBC}$ antibodies were negative (Table 1) and anti-HBs antibodies were positive, as expected in an infant with immunity to HBV infection after vaccination. The echocardiogram at two months of life showed severe left ventricular dilation with depressed systolic function and he was placed on the heart transplant waiting list. He was successfully transplanted at three months of age.

\section{DISCUSSION}

We present a case of a newborn in whom administration of IVIG interfered in the serology result for hepatitis B. This is a rare event and has never been described at such an early age and in this particular setting. Its recognition was key as he was a patient who could need cardiac transplantation and immunosuppressive therapy, with the consequent risk of viral reactivation. This reactivation can occur even in persons who are anti-HBs positive, although with a lower risk. As an example, in a prospective study evaluating the risk of $\mathrm{HBV}$ reactivation in 150 antigen $\mathrm{HBs}$ negative and anti-HBc positive patients undergoing chemotherapy with a rituximab-containing regimen for lymphoma, HBV reactivation occurred in nine of the 116 patients (8\%) who were positive for anti-HBs at baseline and eight of the $35(23 \%)$ who were negative for anti-HBs. ${ }^{5}$

Dilated cardiomyopathy (DCM) is defined by dilation and systolic dysfunction of the left ventricle (LV) or both ventricles not explained by abnormal ventricular filling conditions (e.g., arterial hypertension, valvular disease) or coronary disease. ${ }^{6}$ Its etiology includes idiopathic DCM, familial DCM, viral, autoimmune or toxic myocarditis and metabolic disease. The most common cause of acquired DCM is viral myocarditis. Therapy in the neonatal period is extrapolated from children and adult data. ${ }^{7}$ One of the possible treatments of viral myocarditis DCM is intravenous immunoglobulin infusion. ${ }^{8}$ Treatment of DCM with refractory heart failure is cardiac transplantation. ${ }^{9}$

Arnold et al described an abnormally high rate of anti$\mathrm{HBC}$ seropositive patients during a rituximab clinical trial. ${ }^{1}$ The authors concluded that 10 out of the 11 seropositive patients had received IVIG therapy in the previous four weeks and found that seven of these patients reverted to seronegative after repeated testing. The patients were screened for HBV infection due to the risk of hepatitis $B$
Table 1 - Results from hepatitis B virus research

\begin{tabular}{|c|c|c|c|}
\hline & $\begin{array}{c}23 / 01 / 2017 \\
\text { (8 days } \\
\text { of life) }\end{array}$ & $\begin{array}{c}26 / 01 / 2017 \\
\text { (12 days of life } \\
-1 \text { day post } \\
\text { IVIg) }\end{array}$ & $\begin{array}{c}\text { 09/03/2017 } \\
\text { (44 days of life } \\
-33 \text { day post } \\
\text { IVlg) }\end{array}$ \\
\hline Antigen HBs & $\begin{array}{l}\text { Insufficient } \\
\text { Sample }\end{array}$ & $\begin{array}{c}\text { Negative } \\
(0.45)\end{array}$ & $\begin{array}{c}\text { Negative } \\
(0.62)\end{array}$ \\
\hline $\begin{array}{l}\text { Antibody } \\
\text { anti-HBc }\end{array}$ & $\begin{array}{c}\text { Negative } \\
(2.07)\end{array}$ & $\begin{array}{l}\text { Positive } \\
(0.03)\end{array}$ & $\begin{array}{c}\text { Negative } \\
(1.48)\end{array}$ \\
\hline $\begin{array}{l}\text { Antibody } \\
\text { anti-HBs }\end{array}$ & & $\begin{array}{l}\text { Positive } \\
\text { (> 1000) }\end{array}$ & $\begin{array}{l}\text { Positive } \\
\text { (202) }\end{array}$ \\
\hline $\begin{array}{l}\text { Antibody } \\
\text { anti-HBc IgM } \\
\text { class }\end{array}$ & & $\begin{array}{l}\text { Negative } \\
(0.08)\end{array}$ & \\
\hline Antigen $\mathrm{HBe}$ & & $\begin{array}{c}\text { Negative } \\
(0.10)\end{array}$ & \\
\hline $\begin{array}{l}\text { Antibody } \\
\text { anti-HBe }\end{array}$ & & $\begin{array}{c}\text { Negative } \\
(1.20)\end{array}$ & \\
\hline
\end{tabular}

reactivation after immunosuppressive therapy. The authors stated that, in order to avoid misleading results, anti-HBc antibodies should only be evaluated either before or three months after the administration of IVIG. In our case, hepatitis B core antibodies were negative one month after IVIG infusion. We conducted a brief review of the literature which showed two more clinical cases ${ }^{2,3}$ and a prospective study ${ }^{4}$ that also reported this phenomenon.

Our patient, a newborn with no identifiable cause for infection since his mother was hepatitis B seronegative and had no significant changes in liver markers, had a likely exogenous source of hepatitis B core antibodies, confirmed by their seroreversion at 44 days of age. Hepatitis B surface antibodies were and remained positive, as expected after successful vaccination.

Information provided by the manufacturer of the drug used, Octagam ${ }^{\circledR} 5 \%,{ }^{10}$ states that it is composed of $\geq 96 \%$ human IgG and prepared by fractionating fresh frozen plasma donated by the general population. Each preparation is made from a plasma pool of not less than 3500 donations. General measures to avoid transmission of infectious agents through the product include selection of donors, screening of individual donations and pooling of plasma for specific markers of infection, and inclusion of steps for inactivation and viral clearance. Viral inactivation of the product is carried out using the solvent/detergent method with a mixture of octoxynol (triton X-100) and TnBP (tri n-butyl phosphate) and a specific treatment with $\mathrm{pH} 4$. The final product is tested for HBs antigen and HIV $1 / 2$ antibodies. It is known that the infectious risk with immunoglobulin administration is extremely low. ${ }^{11}$ The requirements for donor screening and infectious disease testing are generally stringent and the manufacturing process normally includes 1 to 2 steps of viral inactivation. ${ }^{10}$ The manufacturer's information further states that, with the administration of IVIG, various antibodies may be passively transferred to the patient's blood, which may lead to positive serological tests. The half-life of the drug is 36 to 40 days, which agrees with the evolution of the patient's serology (Table 1). 


\section{PROTECTION OF HUMANS AND ANIMALS}

The authors declare that the procedures were followed according to the regulations established by the Clinical Research and Ethics Committee and to the Helsinki Declaration of the World Medical Association.

\section{DATA CONFIDENTIALITY}

The authors declare having followed the protocols in use at their working center regarding patients' data publication.

\section{REFERENCES}

1. Arnold DM, Crowther MA, Meyer RM, Carruthers J, Ditomasso J Heddle NM, et al. Misleading hepatitis B test results due to intravenous immunoglobulin administration: implications for a clinical trial of rituximab in immune thrombocytopenia. Transfusion. 2010;50:2577-81.

2. Ilboudo CM, Guest EM, Ferguson AM, Garg U, Jackson MA. Misleading hepatitis $B$ testing in the setting of intravenous immunoglobulin. F1000Res. 2013;2:249.

3. Parker S, Gil E, Hewitt P, Ward K, Reyal Y, Wilson S, et al. Case report: passive transfer of hepatitis $B$ antibodies from intravenous immunoglobulin. BMC Infect Dis. 2014;14:99.

4. Ramsay I, Gorton RL, Patel M, Workman S, Symes A, Haque T, et al Transmission of hepatitis $\mathrm{B}$ core antibody and galactomannan enzyme immunoassay positivity via immunoglobulin products: a comprehensive analysis. Clin Infect Dis. 2016;63:57-63.

5. Hsu C, Tsou HH, Lin SJ, Wang MC, Yao M, Hwang WL, et al. Chemotherapy-induced hepatitis $B$ reactivation in lymphoma patients with resolved HBV infection: a prospective study. Hepatology. 2014;59:2092-100.

6. Elliott P, Andersson B, Arbustini E, Bilinska Z, Cecchi F, Charron P, et al.

\section{INFORMED CONSENT}

Obtained.

\section{CONFLICTS OF INTEREST}

All authors report no conflict of interest.

\section{FUNDING SOURCES}

The authors declare that there were no external sources of study for the performance of this article.

Classification of the cardiomyopathies: a position statement from the European Society Of Cardiology Working Group on Myocardial and Pericardial Diseases. Eur Heart J. 2008;29:270-6.

7. Soares P, Rocha G, Pissarra S, Soares H, Flôr-de-Lima F, Costa S, et al. Neonatal dilated cardiomyopathy. Rev Port Cardiol. 2017;36:201-14.

8. Drucker NA, Colan SD, Lewis AB, Beiser AS, Wessel DL, Takahashi M, et al. Gamma-globulin treatment of acute myocarditis in the pediatric population. Circulation. 1994;89:252-7.

9. Birnbaum BF, Simpson KE, Canter CE. Heart transplantation in pediatric cardiomyopathies. Expert Rev Cardiovasc Ther. 2013;11:1677-90.

10. Octagam ${ }^{\circledR} 5 \%$ Product Monograph. OCTAPHARMA Pharmazeutika Produktionsges, m.b.H. Distributed by Octapharma Canada Inc. Date of Revision: August 6, 2014. [accessed 2017 May 29]. Available from: http://www.octapharma.ca/en/healthcare-professionals/productstherapies/products-in-canada.html.

11. Anderson D, Ali K, Blanchette V, Brouwers M, Couban S, Radmoor P et al. Guidelines on the use of intravenous immune globulin for hematologic conditions. Transfus Med Rev. 2007;21:S9-56. 